\title{
The Impact of Architectural Structures from Past to Present on Developing Tourism (Example of the City of Paris)
}

\author{
Parisa Doraj (Corresponding author) \\ Faculty of Architecture and Design, Department of Architecture, \\ Ataturk University, Erzurum, Turkey \\ E-mail: parisa.doraj@atauni.edu.tr \\ ORCID ID: 0000-0001-5954-0173 \\ Iclal Aluclu \\ Faculty of Architecture and Design, Department of Architecture, \\ Dicle University, Diyarbakir, Turkey \\ ORCID ID: 0000-0002-8151-2811 \\ Omid Hossein Eskandani \\ Faculty of Architecture and Design, Department of Architecture, \\ Ataturk University, Erzurum, Turkey \\ ORCID ID: 0000-0002-0218-4187
}

\begin{abstract}
The architecture of cities requires coordinated and consistent efforts to arrange the urban landscape in a way that attracts tourists to the city and the place. Cultural components and their characteristics are very important for the development of urban tourism and the drawing of a spatial and mental image. Spatial and socio-cultural structures and factors play an indispensable role in the development of tourism areas and the emergence of different structures to the forefront in the postmodern era and the spaces created accordingly give cities a special character and draw a mental perspective for individuals and cities.

In this study, we focused on the city of Paris and identified the framework that forms the criteria for cultural tourism venues in the city using an analytical approach and content analysis method, and then examined the factors and phenomena in the development and increase of cultural tourism in these venues. The findings from these analyses show that cultural tourists seek authentic, diverse and creative experiences, and that these places are the building blocks of the city's cultural sites and include public spaces (historical, natural, contemporary cultural, indigenous, unusual places, urban, recreational, commercial). The experiences of tourists are formed in a symbolic and continuous combination of social interactions, as well as fixed and temporary physical characteristics and the cultural meaning of space.
\end{abstract}

Keywords: Urban Space, Iconic Structures, Cultural Components, Urban Tourism

DOI: $10.7176 /$ JSTR/7-09-02

\section{Geçmişten Günümüze Mimari Yapılarının Turizm Gelişimi Üzerinde Etkisi (Paris Kenti Örneği)}

Özet

Şehirlerin mimarisi, pratikte turistlere sunulan ziyaretçilerin olumlu beklentilerine uygun olarak kentsel peyzajı stabilize etmek ve turistlerin zihinsel manzarasını şehire ve mekana çekmek için eşgüdümlü ve tutarlı çabalar gerektirmektedir. Kent turizminin gelişmesi için mekânsal ve zihinsel bir imaj çizmede

8 | P a g e

www.iiste.org 
kültürel bileşenler ve özellikleri çok önemlidir. Postmodern çağında mekânsal ve sosyo-kültürel yapılar ve etmenler turizm alanların gelişimi ve farklı yapıların ön plana çıkmasında vazgeçilmez bir rol oynamakta ve buna dayalı olarak mekanlar yaratmakta, şehirlere özel bir karakter kazandırmakta, bireylere ve kentlere zihinsel bir perspektif çizmekte çok önemli bir yere sahiptir.

$\mathrm{Bu}$ çalışmada, kentte turistik mekanlarının kültür turizmini çekmek için Paris şehrine odaklanmış, analitik bir yaklaşım ve içerik analiz yöntemiyle kentte kültür turizmi mekanlarının kriterlerini oluşturan çerçeve belirtilmiş ve daha sonra bu mekanların kültürel turizminin geliş ve artışında etken ve olgular incelenmiştir. Bu analizler sonucu elde edilen bulgular, kültür turistlerinin otantik, çeşitli ve yaratıcı deneyimler aradıklarını ve ilgili yerlerin şehirin kültürel yerlerinin yapı taşları olduğunu ve kamusal alanları (tarihi, doğal, çağdaş kültürel, yerli, alışılmadık mekanlar, kentsel, rekreasyonel, ticari) içerdiğini göstermektedir. Turistlerin deneyimlerinde sosyal etkileşimlerin yanı sıra sabit ve geçici fiziksel özellikler, mekanın kültürel anlamının sembolik ve sürekli bir kombinasyon halinde oluşmasıdır.

Keywords: Kentsel Mekan, İkonik Yapılar, Kültürel Bileşenler, Kent Turizmi

\section{Giriş}

Turizm kelimesinin anlamı, seyahat ve turizm yönleriyle bireysel bir çalışmayı ifade eder; Küresel arenada bu mesele ekonomik kökleri ortadan kaldırırken aynı zamanda etkili bir sosyal yük de beraberinde getirmektedir. Aslında, büyük bir kültürel olgu olarak postmodernizm, sosyal farkındalığa ve dolayısıyla yeni kültürel kalıpların yaratılmasına yol açabilecek turizm gibi çeşitli gelişmeleri içermektedir. Öte yandan, bazı yazarlar kültürü, turizmin gelişmesinin temel taşı olarak görmektedirler (Yezdi et al., 2007).

Günümüzde turizm küresel ölçekte özel bir yere sahip olduğundan çoğu ülke sosyo-ekonomik, ekonomik ve kültürel planlamalarına turizmi dahil etmişler. Kent turizmi kavramı, şehirlerin yoğunlaşmanın, siyasi ve ekonomik güç ve gücün merkezi haline gelmesi ve genellikle çok çeşitli tarihi ve kültürel cazibe merkezleri, alışveriş, restoranlar ve kentsel canlılı̆̆ içermesiyle birleşikte 1980'lerde ön plana çıkmıştır (Yılmaz ve diğerler, 2020). Aslında son yıllarda, şehirlerin önemli turizm destinasyonlarına dönüşmesi ile şehir turizminin önemi daha da ortaya çıkmıştır. Turizm uzmanlarına göre şehir turizmi kentlerde büyük bir kültürel, sosyo-ekonomiye firsat yaratır ve bu firsat farklı boyutlarda vatandaşların yaşam kalitesi üzerinde önemli rol oynamaktadır (Richards, 2006).

Son y1llarda turistler için turistik cazibe merkezlerinden biri kentsel mekanlardır. Uzmanlara göre kent turizmi, ana kentler için büyük bir kültürel, sosyal ve ekonomik firsat yaratmakta ve çeşitli boyutlarda vatandaşların tanıtımında oldukça etkin rol oynamaktadır. Bu özel alanlar arasında binalar, anıtlar ve kamusal geçitler şeklinde yıllar içinde yaratılmış semboller, unsurlar ve kalıcıllk işaretleri bulunmaktadır. Günümüzde dünyanın rekabetçi turizm pazarında, şehirlerdeki seçkin mimariler turist çekmede bir başarı faktörü olarak kabul edilmekte ve kentsel simge ve ikonik mimarisi en belirgin rolü kent turizmini güçlendirme olarak değerlendirilebilir (Hossein Eskandani ve Doraj, 2021).

İkonik Mimarlıkta kimlik, tarih ve kültürel unsurlardan faydalanmak kaçınılmazdır, daha öncede değinildiği gibi bu mimari her şehrin kültürel unsurlarının kalbinden çıkmıştır. Günümüzde kent merkezlerini daha çekici hale getirmek için önemli çabalar sarf edilmiş ve bu da kentlerde yaygın mekânsal değişimlere neden olmuştur. Dünyadaki her şehrin kendi formu, gövdesi ve işlevi vardır. Her şehirde, kente daha fazla turist çeken ve elinde tutan farklı faktörler bulunmaktadır (Çelik Başok ve diğerler, 2021). Bunlardan kentsel semboller, kentsel turizmin güçlendirilmesinde turistik çekiciliğin artırılmasında önemli rol oynamaktadır. Aslında kent düzeyinde, kentin farklı bölümlerini monoton ve tekrarlayan bir durumdan çıkaran ve kentin her bir parçasına özel bir kimlik ve özellik kazandıran güzel ve sanatsal mekânsal semboller ve öğeler bulunmaktadır. Binalar uzun zamandır bir kenti diğerinden ayıran şehirlerin kimliği olmuştur; ve onların tarih ve kültürüne göre çeşitli şekiller almışlardır ve turistler için şehirleri birbirinden farklı kılan ikonik ve sembolik binalarmış (Law, 1992: 137; Hossein Eskandani ve Doraj, 2021).

Herhangi bir turistik çekiciliğin başarısı için her destinasyonda çeşitli faktörler rol oynamaktadır; Genel bir kategoride, bu faktörler üçe ayrllabilir: yapısal ve formal (tesisler, konaklama tesisleri, catering, seyahat hizmet ofisleri, satış ve ulaşım gibi hizmet unsurları), fonksiyonel ve işlevsel (tedarik veya destinasyon, turizm sisteminde ve çeşitli ekonomik, sosyal, çevresel vb.) örgütsel ve ölçeklı (rekrasyon alanları, yeşıl bölgeler, ormanlıklar ve büyük tesisler) kategorilere ayrılmıştır (Edwards et al. 2008).

$\mathrm{Bu}$ çalışma, kentsel turistik cazibe merkezlerinin kültürel turistleri çekip çekemeyeceği sorusuna Paris örneği üzerinde cevap aramaktadır. Bu nedenle öncelikle kuramcıların mekan kavramına ilişsin

9| P a g e

www.iiste.org 
görüşlerini, kentsel mekan ve kültür turizmi kavramına ilişkin tanımları kent turizmi mekanlarına ilişkin kavramsal ve işlevsel bir perspektiften inceleyerek analiz edilmiştir. Turistler bir yandan kültürü, diğer yandan kültür turizmi deneyiminin özelliklerinin bileşenlerini yerleştirirken, diğer yandan kent turizmi yerlerinin ve etkin bileşenlerinin turistleri çekmeye olan etkisinin, etkinlik bileşenlerine göre nasıl olduğunu araştırmıştır. Kültürel bileşenlerin kentlerin mimarisi üzerinde büyük bir etkisi vardır ve bu araçlar kullanıldığında bir kent veya mekan Paris, Fransa örneğinde olduğu gibi birkaç alanda ünlü hale gelebilir.

Paris seçkin mimarisinde kültürel bileşenlerin etkin rolü kanıtlamaktadır. Bir şehrin veya mekanın çeşitli tarihi, kültürel, mimari ve modern bileşenleri arasındaki ilişki Paris'te görüldüğü gibi, izleyicinin zihninde nihai olarak şehrin marka imajını yaratan değişkenleri tanımlamayı, kategorize etmeyi, organize etmeyi ve koordine etmeyi gerektirir. Aslında bir yeri indekslemenin amac1, arzu edilen imajı elde etmek ve izleyicide zihinsel bir bakış açısı oluşturmaktır ki bu Paris şehri için de geçerlidir. Kentsel endeks stratejileri kent turizminde önemli bir rol oynamaktadır. Bu strateji doğrultusunda kentin kültürel ve tarihi bileşenlerinden ve halkın katılımından yararlanmış, kentsel turizm markaları altında uygun mimari ile kentin ana markası olan mimariyi sürdürebilmiștir. şehrin turizmi aslında bir yeri indekslemenin amacı, arzu edilen imajı elde etmek ve izleyicide zihinsel bir bakış açısı oluşturmaktır ki bu Paris şehri için de geçerlidir. Kentsel seçkin mimari stratejileri kent turizminde önemli bir rol oynamaktadır. Bu strateji doğrultusunda kentin kültürel ve tarihi bileşenlerinden ve halkın katılımından yararlanmış, kentsel turizm markaları altında uygun mimari ile kentin ana markası olan mimariyi sürdürebilmiştir. Kentsel yapılar ve unsurlar, kentin yaşam kalitesini arttırırken, turistler için çekiciliği ve aktivite süresini ve kentsel güvenliği artırmada ve dolayısıyla kentsel turizmin gelişmesinde önemli bir rol oynayabilir.

Plaza (2000), "Kültürel İnsan Yapımı Atraksiyonların Turist Çekiciliği Üzerindeki Etkisini Değerlendirme" başlıklı bir çalışmada, İspanya'nın Bilbao kentindeki Guggenheim Müzesi'ni insan yapımı bir cazibe merkezi olarak incelemiştir. Kalıs sayısı ve süresi ile gelen turistlerin maliyetini içeren araştırma bilgileri bir anket aracılı̆̆ıyla toplandı ve analiz edildi. Müzenin, Eyfel Kulesi, Özgürlük Anıtı vb. gibi diğer birçok insan yapımı cazibe merkezi gibi, daha fazla İspanyol turisti çeken kentsel bir unsur ve sembol olduğu sonucuna varmıştır.

Gamiti (2012), İtalya'nın Roma kentinin turizm programını eleştirel bir yaklaşımla ele aldığ 1 "Turizm, Kültür ve Kentsel Rekabet, Roma Turizm Planlamasına Eleştirel Bir Yaklaşım" başlıklı bir çalışma yürütmüştür. Bu çalışmada şehirlerin mimari, bina, tema park, müze ve özel kültürel etkinlikler şeklinde sembol ve unsurları kullandığını ve o şehrin turizmini, turizmin kültürünü ve akımlarını ve şehrin silueti de tanıtan turizmi farklılaştırmaya çalışmışlardır. Bu araştırmadan, mevcut Roma kalkınma modelinden kaynaklanan mevcut belgeleri inceleyerek, Roma şehrinin seçilen turizm kalkınma modelinin çelişkilere neden olduğu ve bu modelin revize edilmesi gerektiği sonucuna varmıştır.

\section{Kavramsal Çerçeve}

\subsection{Mimarlıkta Mekân Kavramı}

Mekanı tanımlarken sosyal boyutu hem zihinsel hem de fiziksel boyutlara bağlamıştır. Diğer bir deyişle, mekanın üretimi, işlevsel, değer-kültürel, beşeri, coğrafi, sosyal ve diğer faktörleri değiştirerek farklı zamanlarda değişir. Düşünürlerin çoğu, mekanı tecrübe edenlerin pratik ve sosyal bileşenlerle sürekli bağlantının ne anlama geldiğine işaret etmiş ve bunu mekan kavramı olarak görmüşlerdir (Tschurni, 1990). Schulz (1988), mekan muhatap tarafindan deneyimlendiğinde mekânsal nitelikler kazanır ve zikredilen mekanın, mimari veya kentsel mekana dönüşür. Burada uzamın anlamının deneyimini yansıtan atmosfer veya mekanın özelliği göz ardı edilmemelidir. Ayrıca mekan, bireysel anlamı ve zihinsel haritaların sembolik içeriğini keşfetme girișiminin ve manzaraların tasvirinin yer aldığı zihinsel algı ve temsil alanıyla ilişkili olarak maddi bir doğaya sahip fiziksel alan kavramını sunmaktadır. Bu bileşenler sürekli bir ilişki içindedir ve bu nedenle farklı eylemler, farklı özelliklere sahip yerler gerektirecektir. Schultz (1980), Mekan kavramını incelerken mekanın işlevsel özelliklerini onaylamak üzere, onu daha çok objektif-fiziksel özellikleriyle birlikte niteler, üç boyutlu geometri gibi uzayın da var olan uzayın nesneleştirilmesi ile algılandığına inanmaktadır. Nesnelliği, varoluş alanını sembolik olarak aktaran bir sanat eseri olarak görmektedir.

\subsection{Kentsel Mekân ve Kültürel Turizm Kavramı}

Kentsel alan, açık, yarı açık ve bazen kapalı fiziksel özelliklere sahip, bir dizi fiziksel sembol ve işaretlerle iletişim yoluyla bireylerin simgesel aktivitelerini ve sosyal etkileşimlerini içeren bir alandır.

$10 \mid \mathrm{P}$ a g e

www.iiste.org 
Sonuçta o alanın sembolik anlamını aktaran kamusal alanlardan kaynaklanan bir alandır ve bu durumda bireysel deneyimler kolektif ve paylaşılan anılar yaratabilir (Habib and Huseininia , 2012). Kentler kültürel bir olgu olarak düşünülebilir ve kentsel toplulukların turistik yerler olarak kabul edilmesi, kültür ve medeniyet yaratma kabiliyetlerinden kaynaklanmaktadır. Kentler, bölgeler ve turistik yerler turist çekmek için giderek daha fazla rekabet etmektedirler (Çelik Başok, 2017).

Kentler kültürel bir olgu olarak düşünülmelidir ve kentsel toplulukların turist hedefleri olarak beğenilmesi aynı zamanda kültür ve medeniyet yaratma yeteneklerinden kaynaklanmaktadır. Şehir veya mekan mimarları istedikleri yeri bir kimlik ve kültürel yaklaşımla tasarlarken kültürel bileşenleri kullanacak, kültürel, dilsel, etnik, dini farklıllklara saygı, kültürel bütünleşme, aşiretlerin kimliğine aidiyet ve sadakati gibi şeyleri içermelidir. Mimariden çok daha karmaşık ve duyarlı olan kentin, geleneklere bağlılık, sembollere, ikonler, desenlere ve mitlere saygı konusu öne çıkmaktadır (Estifanos, 2009).

Kültürel bileşenler kent mimarisinde kullanılmasının yanı sıra çeşitli cazibe merkezleri şeklinde ortaya çıkmıştır ve turizmi şekillendirmede, insanları ve sermayeyi şehirlere çekmede önemli bir role sahip olmuștur. Şehirler sürekli geliștikleri nedeniyle, konumlarının ideal yüzünü gösterebilecek şekilde olması gerekir. Bu nedenle, şehirlerin kendilerini tanıtmalarında gereken şey; "itibar" olmalıdır, bu ise turizm almak ve turizm göndermek işlevinde önemlidir ve söz konusu itibarı kazanmada kültürel bileşenler çok önemli rol oynamaktadır (Boniface, 2013).

kültürel turizmi, bir topluluğun kültürel özelliklerini yansitan mirasa veya bilimsel, sanatsal ve tarihi yaşam tarzına tam motivasyon ve ilgi duyan, ev sahibi olmayan bir topluluktan bireylerin ziyareti olarak tanımlar. kültür turizmini kültürel miras turizmi olarak tanımlamıştır ve böylece sanat gezileri mirası ve otantik bir yerin tüm eşsiz kültürel özelliklerini içerir. Tarihi ve modern mekanların çeşitli mimari çekiciliğine sahip kentler, kentte turizmin oluşumunda farklı insanları cazb etmede önemli rol oynamaktadır (Yezdi et al., 2007).

Aynı zamanda kent, pek çok kişi tarafindan, şehrin doğal-fiziksel çevresi üzerindeki sürekli kültür değişimlerine dikkat eden kapsamlı bir sürecin bir sonucu olarak tanımlanmaktadır, Öte yandan, kültür olağanüstü bir güce sahiptir ve kültür turistleri için mekândaki bariz ve görünmez mirasını ortaya çıkarabilen kent turizminin başlıca cazibe merkezleri olarak kabul edilmektedir (Jelincic, 2001). Aslında, kentler günlük yaşamın kültürlerinin inşası ve deneyiminde çok önemli bir rol oynamaktadır. Kentteki ve kentsel mekândaki kültürel turistler geleneksel kültüre sahip yerler ve kültürel anlam elde etmek için kültürel ve otantik deneyimler aramaktadırlar (Estifanos, 2009: 104; Hossein Eskandani, 2020: 63).

\section{3. İkonik Mimari ve Turizm Gelișiminde Rolü}

Oxford Sözlüğüne göre, "Ikon”, bir konuyu temsil etmesi gereken bir şeydir. Bir görüntü, bir form, bir yüz, bir illüstrasyon veya bir heykel, bu iki tanımlayıcı özelliğe sahip oldukları sürece "Ikon" olabilirler: Birincisi, en azından bir grup içinde açıkça biliniyor olmaları ve ikincisi, İkonik özelliklere ve estetik ilkelere sahip olmalarıdır. Bu şöhretin ile estetik niteliklerin bir kombinasyonudur ve göstergenin (Icon) yapısını oluşturmaktadır. "Gösterge Mimarlı̆ı̆ı" tarihinde sembolizme, tezahüre ve temsil etme özelliklerine sahiptir.

Her ne kadar ikonik mimarisi tanımında sembolik ve estetik konseptini ifade etse de İkonik mimari form odaklıdır. Oxford Sözlügünde İkon, mimari için hantal, heybetli, kaliteli ve dikkat çeken bir nitelik olarak kabul görmektedir. Genellikle İngilizcede "monumental", boyut olarak doğal olmayan, biçim olarak heykelsi ve son derece güçlü olan bir şeyi ifade etmektedir. Monumental kelimesinin Latince'deki, kökü uyarmak anlamına gelen monere kelimesinden gelmekte ve daha çok tarihi anımsatan bir bina için kullanılmaktadır.

Tschurni (1990)' ye göre, ikonik yapılar, konumları, boyutları ve büyüklükleri nedeniyle hantal konumlarıyla değerlendirilmektedir. Soja (1990)' ya, ikonik mimariyi, kutsal unsurları uygulayarak güzel ve saygın bir şey yaratan, pahalı yapılar ve sanatçılar tarafından oluşturulan gücün bir yansıması olarak görmektedir. Lefebvere (1990)'e göre ikonik mimarinin en önemli özellikleri düzenlilik, sembolizm ve ona güç veren iletișimdir.

İkonik mimarinin kavramsal olarak monumental mimarisi ile uyumlu olduğu söylenebilir, ancak İkonik mimarisi, boyut ve şekil bakımından İkonik mimari kadar hantal ve güçlü olmak zorunda değildir.İkonik mimari zorunlu olarak gösterge mimarisidir, ancak gösterge mimarisi mutlaka İkonik değildir. Bir park, bir kamusal alan veya özel malzemeli küçük ölçekli bir proje, İkonik mimarinin fiziksel özelliklerini taşımadan bir şekilde kentsel semboller haline gelebilir (Jelincic, 2001). İkonik mimarinin farklı ve benzersiz bir alan veya bina olduğuna inanmaktadır, ünlü olmak için tasarlanmış,

11 | P a g e

www.iiste.org 
kendine has İkonik ve estetik nitelikleri bulunmaktadır. Bu tanımda, göstergesel yapılar inşa edilmeden önce bile İkonik olacak şekilde tasarlanmıştır. Tüm sanat eserleri tipik olarak bir şeyi veya bir duyguyu temsil eder, sembolize eder veya ifade eder (Schulz, 1980: 109). Soja (1990)'ya göre, İkonik mimarisi için aşağıdaki özellikleri listelemektedir: 1. seçkin olma duygusuna sahiptirler 2. Duygusal ve nettirler 3. Mükemmelliğin somutlaşmış halleridirler. 4. Sıkıştırılmış, sembollerin ve işaretlerin yerini alan gizemli bir kişiliğe sahipler. Genellikle sessizdirler ve hipnotik bir kaliteye sahiptirler.

İkonik yapılarının genel özelliklerinin yanı sıra konumları da önemlidir. İkonik binaların sabit yerlerde bulunduğu açık olsa da, önemlerinin coğrafi ölçeği sabit değildir. İkonik mimariler yerel, ulusal, küresel veya her üçü boyutta değerlendirilebilir. Pek çok ikonik bina ve alan kentsel işaretler olsa da, tüm kentsel ikonikler gösterge yapılar değildir. Kentsel ikonikler çevrelerine göre çoğunlukla yüksektir, ancak ikonikler mutlaka yüksek değildir ve yüksek yer işaretleri dışındaki unsurlar onları mekan simgeleri haline getirebilir, ancak bu mekan simgelerinin yüksek olamayacağı anlamına gelmez (Strange and michael, 2002).

Yerel ikonik yapılar, popüler olan ve genellikle mahalle veya şehir genelinde bir kimlik sembolü olarak kabul edilen binalar ve alanlardır. Bu şehirlerle ilgilenen yabancılar için ilginç olabilirler. Kesinlikle Londra, New York ve Paris gibi büyük şehirlerin ikonik yapıları, bu ülkelerdeki küçük şehirlerin yerel göstergelerinden daha iyi bilinir. Ancak aynı ikonler daha küçük şehirleri de harita üzerine çekebilir. $\mathrm{Bu}$, şehirlerin dikkatini çeken tanıdık bir olgudur. Kentsel ilgiyi çekmek, kasıtlı göstergeler yaratmanın en mantıklı nedenlerinden biridir. Günümüzde turistler için turistik cazibe merkezlerinden biri kentsel mekanlardır. Bu özel alanlar arasında binalar, anıtlar ve kamusal geçitler şeklinde yıllar içinde yaratılmış semboller, ikonik yapılatr, unsurlar ve kalııılık işaretleri bulunmaktadır (Pearce, 1991: 135).

Bugün dünyadaki rekabetçi turizm pazarında, şehirlerdeki ikonler, turist çekmede bir başarı faktörü olarak kabul edilmekte ve şehir sembol ve illonlerin şehir turizmini güçlendirmedeki en bariz rolü olarak değerlendirilebilmektedir. Antik, ulusal ve dini isimleri ve sembolleri ile dünyaca ünlü şehirlerdeki en büyük ve en önemli turistik yerler bulunmaktadır. Bir bakıma dünyadaki her önemli şehrin özel bir sembolle bilindiği ve bu konunun tüm önemli şehirlerde görülebildiği ve turistlerin gezilerini bu eserlerin popülaritesine göre planladıkları ve bu bölgeleri ziyaret etmek için seyahat ettikleri söylenebilir.

\section{Araştırmanın Materyali ve Yöntemi}

Paris'te bulunan mimari yapılar turist çekme konusunda önemli rol oynamaktadır. genel olarak bir kentte yeni ve tarihi yapılar birlikte yan yana gelmeleri ve bir kompozisyon oluşturmaları turistin ihtiyaçlarını karşlayacak şekilde düzenlemeler, şehrin turist çekmek konusunda önemlidir. Paris'te bu hususlara dikkat ederek yanı sıra kültürel ve oyun ve eylence mekanları birlikte olduğunda dayalı Paris'e değer kazandırdığını ve her sene turistin artışına sebep olmuştur (Şekil 1). Araştırmanın ana yaklaşımı analitik bir sürece dayanmaktadır ve araştırma konusuna göre araştırma yöntemi kütüphane ve belgesel çalışmalara dayanmaktadır. Çünkü bu çalışmanın amacı, bir yandan kent turizmi mekanlarının etkili bileşenlerini açıklamak, diğer yandan kültürel turistlerin deneyimlerinin özelliklerinden kaynaklanan alanları ve bileşenleri belirlemek ve böylece iki bileşenin kentin cazibesini nasıl etkilediğini açıklamaktır. $\mathrm{Bu}$ nedenle, istenen hedefe ulaşmak için genel olarak bilgi analizi yöntemi olarak içerik analiz seçilmiştir. Dolayısıyla öncelikle kuramcıların mekan kavramındaki bakış açısını mekana göre istenilen şekilde inceleyip analiz edilmiştir. Her bakış açısında kullanılan kelimeleri analiz ederek ve ilgili kelime ve kavramlara soyut analizler sunarak, sonra kentsel alan ve kültür turizmi tanımları ve kavramları ile ilgili bilgilerin kentsel turizm mekanlarına ilişkin kavramsal ve işlevsel perspektiften analitik çalışılması ve görsel sıralaması ile kültürel turistlerin deneyimlerinin özellikleri perspektifinden temel ilişkileri incelemeğe ve analiz edilmeye çalışılmıştır. Elde edilen analizlere ve soyut analitik özetlere dayanarak tanımlar ve sonra bir yandan kültür turizmi mekanlarının kurucu bileşenlerinden ve doğasından türetilen bileşenlerden bir çerçeve ve model sunulmuştur. Diğer yandan kültürel turistlerin deneyimleri dikkate alınmıştır. 


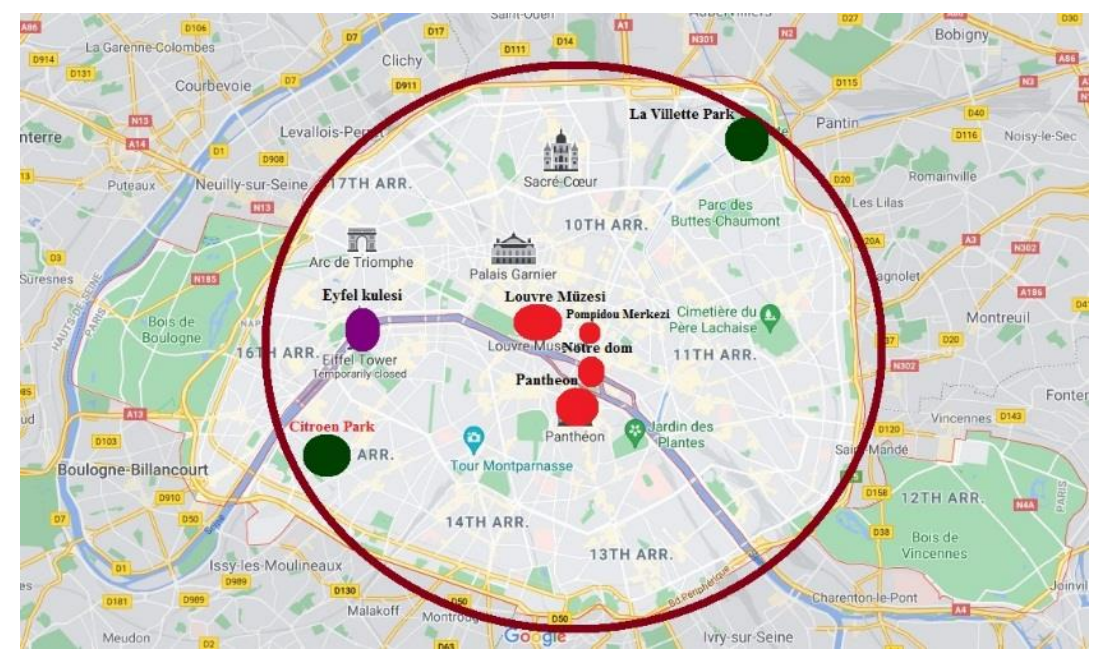

Şekil 1. Paris'in merkezinde $10 \mathrm{~km}$ çapında bulunan ikonik binalar (Orijinal)

\section{Bulgu Ve Tartışmalar}

\section{1. İkonik Mimarinin Ayrımı}

Binalar genellikle kar etme firsatları olarak görülür, bu nedenle nadir ve benzersiz bir yapı inşa etmek katma değer yaratabilir. Performansı dengelemek ve binanın öncü olması geliştiriciler için her zaman bir düşünme kaynağı olmuştur. Bununla birlikte, 1970'lerin sonlarında ve 1980'lerin başlarında postmodern mimarinin ortaya çıkmasıyla, mimarinin genel halkla bağlantısı fikri ortaya çıktı. Postmodern mimarisi, mimari değerlerini koruduğu gibi, halk tarafindan da anlaşlabilir ve beğenilebilirdi. O dönemin ünlü mimarları (Starchietcs) çok az iş yapsalar da, kâğı üzerindeki mimarileri de en azından çeşitli mimarlık dergilerinde yayınlandı ve korundu (Pearce, 1991). Ancak paralel olarak, mühendislik yapılarını ve sistemlerini sergilemeyi amaçlayan bir mimari olan postmodern mimarinin yanı sıra yüksek teknoloji mimarlarda bulunmaktadır. $\mathrm{Bu}$ mimarinin güzel bir örneği, Renzo Piano ve Richard Rogers tarafindan Paris'te bulunan Georges Pompidou Kültür Merkezi'dir. Bu tekli mimarilerin gösterdiği şey, endüstriyel estetiğin genel ilgi alanı olduğudur. $\mathrm{Bu}$ sorun, dekonstrüktivizm mimarisinde de kendini gösterdi. Bu tarzın en ünlü mimarı, en azından 1970'lerde Faranak Gehari dir (Şahin and Akdoğdu, 2004).

20. yüzyılın başlarından bu yana kentsel nüfusun artmasıyla birlikte ekonomistler, küreselleşmenin ve çokuluslu şirketlerin gücünün güç dengesini milletlerden şehirlere kaydıracağını ve bundan sonra şehirlerin komşu şehirlerle rekabet edeceğini tahmin etmektedir. Böylelikle şehirler kültürel değerleri ön planda tutarak kendilerini "yeniden üretmeye" çalışırlar. Belediyeler ve kar amacı gütmeyen kuruluşlar, ünlü mimarlardan (Starchietcs) yararlanarak yeni tesislerine turizm gelirini artırmayı umut etmektedirler (Akyol et al., 2014).

1990'larda, mimaride faktör olarak adlandırılan şaşırtıcı (WOW Factor) bir terim, özellikle İngiltere ve Amerika Birleşik Devletleri'nde popüler hale geldi. Bu faktör, ilk başta izleyiciyi hayrete düşüren binalar için kullanıldı. Hatta bu alanda bilimsel araştırmalar yapılmış, zihni ve duyguları etkileme konusu ele alınmıştır (Dumont et al. 2005).

İkonik mimari çeşitleri özelliklerine göre üç kategoriye ayrılabilirler:

- Form eksenli gösterge mimarisi

- Fonksiyonel eksenli gösterge mimarisi

- Ölçek eksenli gösterge mimarisi

Paris dünyanın en fazla turiste çekici olan kent olarak mimari binalarında üç önemli ayrım, forum ağırlık, fonksiyonel ağılık ve ölçek ağırlık konusunda çok zengin yapıya sahiptir ve ayrıca her döneminde meşhur ve simgesel eserlerin içermektedir.

\subsection{Form eksenli gösterge mimarisi (Fiziksel)}

İkonik mimarisine ulaşmanın bir yolu, formu kullanmaktır. Mimari çalışmada izleyiciyle ilgili ilk katman olan form, izleyici üzerinde yüksek bir etkiye sahiptir ve yoldan geçen herkesin dikkatini 
çekebilir. İzleyiciyi cezbetmek için çekici bir form kullanan ve dolayısıyla göster haline gelen projelerin çoğu aynı özelliği kullanmış ve öne çıkan mimariler arasında yer alabilmiştir. Ancak ikonik mimarisini elde etmek için formu kullanmanın, politika yapıcıların bir dizin projesi oluşturmak için bu stratejiyi kullanırken farkında olmaları gereken kendi zorlukları ve karmaşıklıkları vardır. Form eksenli mimaride en önemli hususlardan biri mimardır. Mimarın formu kullanma tarzı, bir projeyi bir simgeye dönüştürebilir veya onu eski, modası geçmiş, boşuna masraf yapılmış bir projeye dönüştürebilir. Formların farklı dönemlerde farklı anlamları ve uygulamaları olmuştur ve tasarımcının bu teorik temeller hakkında bilgi sahibi olması ve mimari gelişmelerin güncel odağında olması ürünü garanti edebilecek duruma getirebilmektedir (Hossein Eskandani, 2020). Dolayısıyla burada özel mimarlar ve yeni çağda form eksenli mimari yaratmadaki rolleri olarak adlandırılan yeni bir konu oluşmaktadır.

Eyfel kulesi 300 metre yükseklikle sanayi devriminde yapılan eser şuan Paris'in simgesine dönüşmüş olup ve yılda 6 milyon turistten fazla bu şehire sadece Eyfel kulesini görmek için gidiyormuşlar. Kültür merkezi Georges Pompidou çok farklı ve sıra dışı form ile yüksek teknoloji doğumuna sebep olan Renzo Piano ve Richard Rogers in meşhur eseridir birlikte teknoloji akımı ortaya çıktı ve her yıl yaklaşık 3 milyon turist bu binayı ve içinde sergilenen eserleri ziyaret etmektedir. Louis Vuitton Foundation Müze ve kültür merkezi çok farklı yapısıyla yeni dönemin dikonstruktivism akımın temsil eden Frank Gehry'nin eseridir. biyoteknik ve çevre dostu olarak her sene 2 milyondan fazla turistlerin gezilebilir mekanına dönüşmüştür (Tablo 1).

Tablo 1. Paris'te İkonik binaların tanıtımı

\begin{tabular}{lll}
$\begin{array}{l}\text { Form ă̆ırlıkıı } \\
\text { yapılar }\end{array}$ & $\begin{array}{l}\text { Ortalama } \\
\text { yıllık turist } \\
\text { sayısı }\end{array}$ & Yapılar \\
\hline
\end{tabular}

6 milyon

Eyfel Kulesi

(1889)
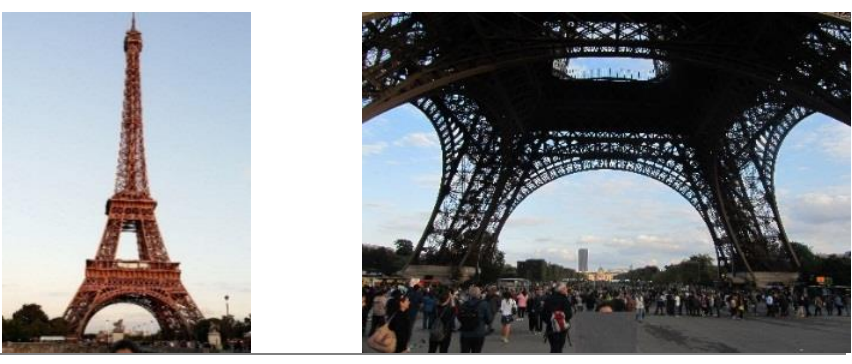

3.5 milyon

Georges Pompidou

Kültür merkezi

(1977)
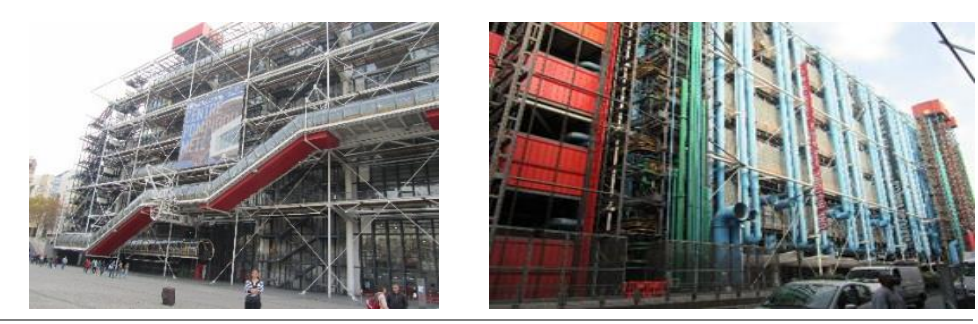

Louis Vuitton
Foundation Müze
ve kültür merkezi
(2006)

2.5 milyon
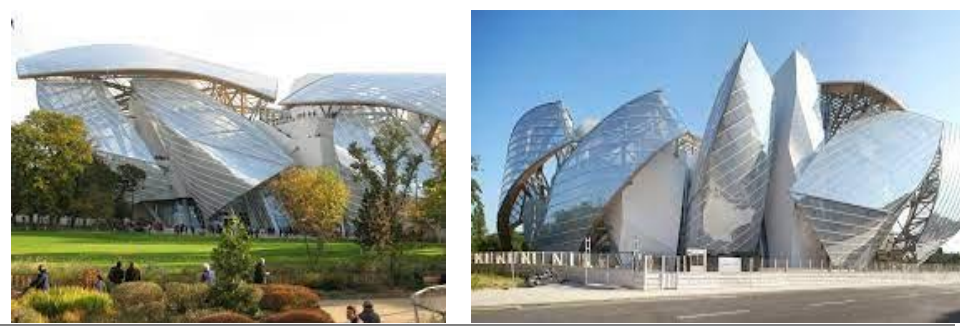

\subsection{Fonksiyonel eksenli gösterge mimarisi}

Bir ikonik mimarisi oluşturmanın başka bir yolu, alanda özel bir işlev oluşturmaktır. Şehirlerdeki işlevlerin çeşitliliği nedeniyle, özellikle bu işlev geniş bir izleyici kitlesini kapsadığında özel bir işlevsel durum yaratır. Örneğin, eğlence, öne çıkan bir mimari oluşturmaya yardımcı olabilir. Başarılı olmuş ve parlak sonuçlar doğurmuştur. Bu mimaride sosyo-ekonomik konulara ve şehir planlamasına 14 | P a g e www.iiste.org 
dikkat etmek, nüfusu ve dolayısıyla kimliğin yaratıcısını çekmesi beklenen bir işlevi seçmek önemlidir ve dikkatli yapılması gerekmektedir (Doraj, 2020: 56).

Temel fizibilite çalışmaları yapmak, şehirdeki kuruluş ve performans yönlerini incelemek performans odaklı bir gösterge mimarisi oluştururken dikkat edilmesi gereken bir diğer konudur. Paris'te eski ve tarihi binalar yeni yapılar kadar değerli ve çekicidirler ve turist gelişimine sebep olmuşlar. mesela Sacré-Coeur bazilikası müzesinde yıllık 11 milyon turistle Paris'te birinci mimari eseri olarak tanımlanmaktadır. Genel olarak tarihi binalara müze ve restoran gibi bir işlev vererek binayı canlandırıp ve ziyaretçiye göre daha anlamlı yapıyorlar ve ziyaretçi bina özelliklerini ve sergilenen eşyanı aynı zamanda görmektedir.

Notre Dame Kilisesi 12. Yüz yılın gotik akımının simgesel ve mükemmel eseridir ve her sene yaklaşık 12 milyondan fazla ziyaretçi kabul etmektedir ve hala dini ibadetler içinde yapılırmıştır. Paris'te inşa edilen ilk büyük anıt, Pantheon 18.Yüzyılda gotik ve yunan mimarisinin karışımı olarak yapılmıştır sade ve geometriksel tasarımıla her sene yaklaşık 5 milyon insan ziyaret etmektedir. Orsay Saray aynı diğer tarihi eserler olarak müze işleve üstlenir her sene 3 milyondan fazla turist bina ve sergi ziyaretine gidilmektedir (Tablo 2).

Tablo 2. Paris'te fonksiyonel binaların tanıtımı

\begin{tabular}{llc}
\hline $\begin{array}{l}\text { Form ağırlıklı } \\
\text { yapılar }\end{array}$ & $\begin{array}{l}\text { Ortalama yıllık } \\
\text { turist sayısı }\end{array}$ & Yapılar \\
\hline
\end{tabular}

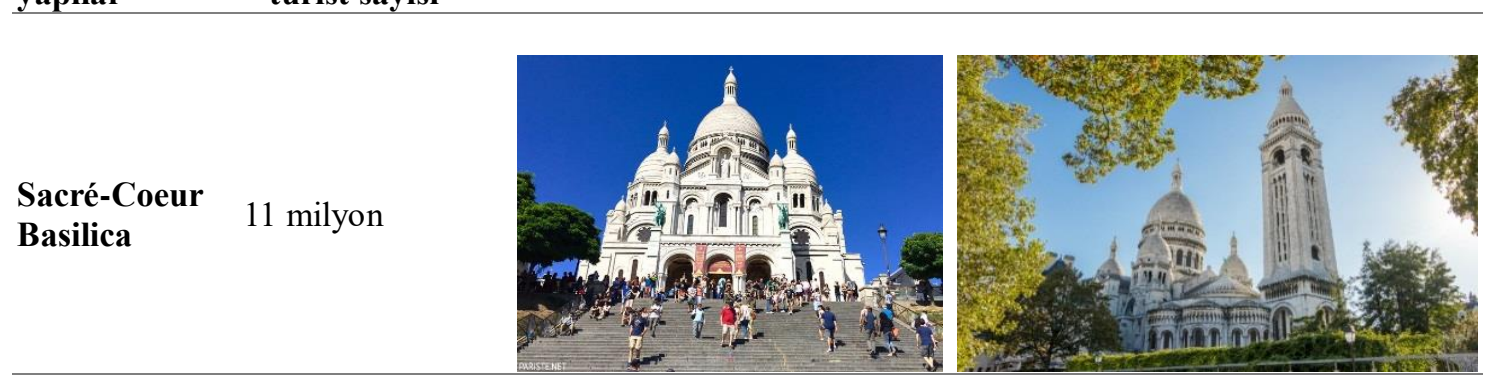
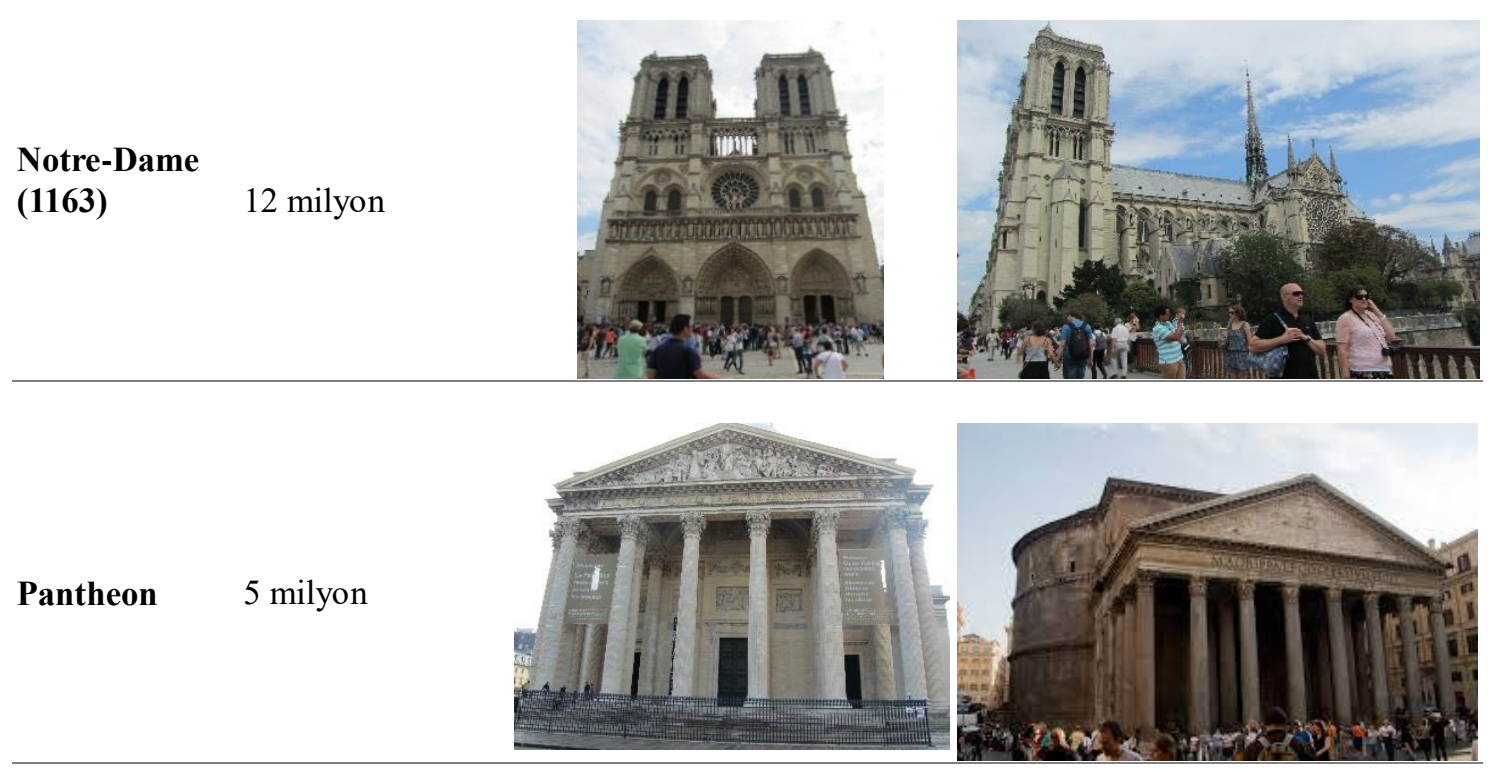

Orsay Müzesi 3 milyon
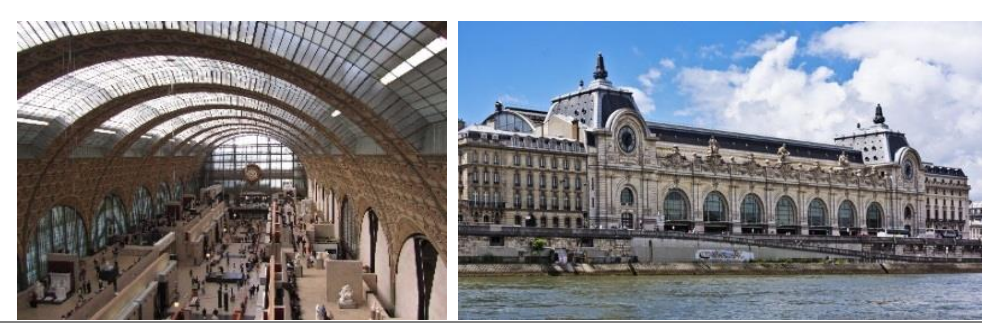

15 | P a g e

www.iiste.org 


\section{4. Ölçek eksenli ikonik mimarisi (Fiziksel)}

Bu kategoride projeyi ünlü yapan, projenin boyutlarıdır. Bu nedenle bu kategori İkonik mimariye çok benzer. Geniş bir yüzeye veya yüksekliğe sahip dev projeler bu mimarisi kategorisine girer. Bu projeler, yıldız mimarlar tarafından tasarlanmaktan veya karmaşık ve hesaplanmış ekonomik teklifler şeklinde onaylanmaktan ziyade genellikle ekonomik yetenekler ve finansman kaynakları açısından tanımlanır. Mimari yapıları ve peyzaj mimarlığının boyutu ve ölçeği, form ve fonksiyonel gibi bir kentin ikonik yapısına dönüşmesi ve turist için çekicini olmasını sebep olmuştur.

Louvre müzesi bir kraliyyet saray bahçesi 16 . yüzyılda barok dönemi temsil eden ve aynı zamanda ölçeğiyle dünyanın en büyük müzesi olarak birinci sırada yer almıştır. Bu müze muhteşem eserleri sergileyen ve aynı zamanda barok binası ve bahçesi ile her yıl 10 milyondan fazla ziyaretçi gelişimine sebep olmuştur. Paris'in 10 kilometre çaplı dairenin içerisinde merkezinde Citroen park1 14 hektar olarak yer almaktadır, bu park model döneminde 1992 Citroen araç fabrikasının üzerinde çevre kirliliğini önlemek için yapılmış ve modern ve anlamlarını taşımaktadır. Son olarak la villette parkı yaklaşık 55 hektar olarak 20 yüzyılında Bernard Tschumi ve Peter Eizenman tarafindan tasarlanmış, parktan ziyade dekonstrüktivizm akımını ve anlamlarını taşımaktadır ve dünyada en önemli dekonstrüktivist örneklerinden biridir (Tablo 3).

Tablo 3. Paris'te fonksiyonel binaların tanıtımı

\begin{tabular}{lll}
\hline $\begin{array}{l}\text { Form ağırlıklı } \\
\text { yapılar }\end{array}$ & $\begin{array}{l}\text { Ortalama yıllık } \\
\text { turist sayısı }\end{array}$ & Yapılar \\
\hline
\end{tabular}

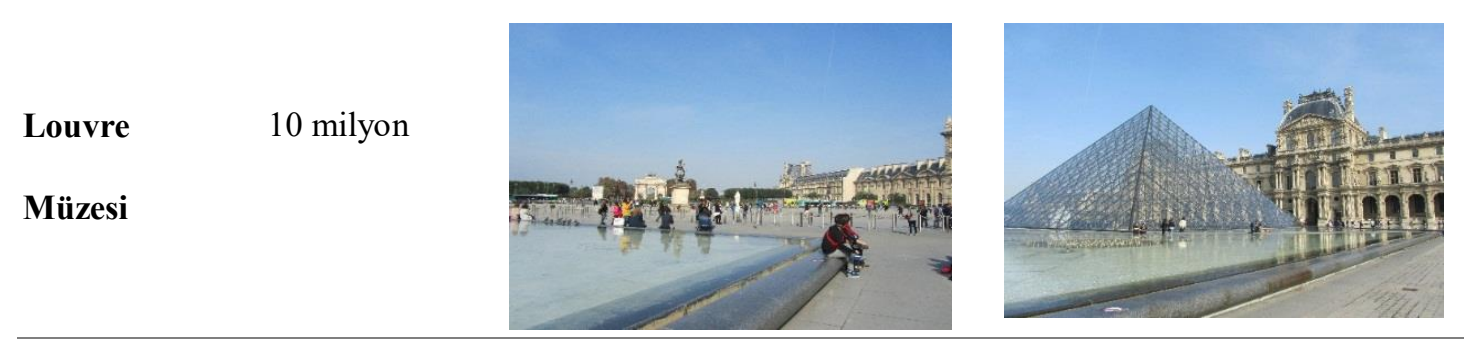

Citroen Park 5 milyon
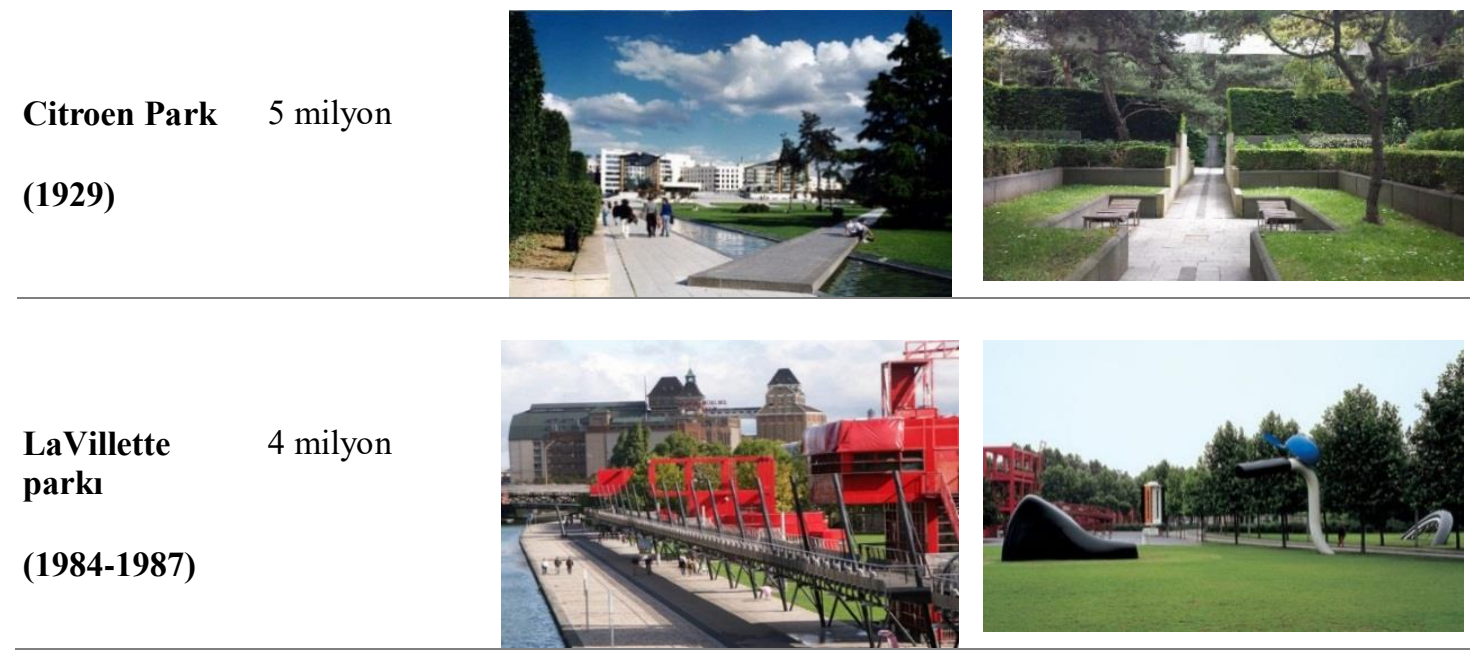

\section{Sonuç}

Bir kentin ziyaretçi sayısı daha doğrusu turist alama kapasitesi farklı faktör ve parametrelerde ölçmekte ve dünya turist indeksine göre derecelendirilmektedir. Bu araştırma mimari mekânların kalitesine göre turist sayısının ilişkisini Paris kentinde incelemiştir. Mekân çeşitliliği ve zenginliği ayrıca konuma ve dağlımı değerlendirilmiş ve incelenmiştir. Araştırmadan elde edilen bulgular sonucu turistik bir şehrin belirgin mimari mekânları olması, tasarlanması ve iyi yerleştirilmesi önemli faktörlerden biri sayılmaktadır. Elde edilen veriler kısaca tablolarla sınıflandırılmıştır. Turistik kentin vizyon proje ve mekanları olmalıdır. Bu konuda ikonik yapılar, simgesel anıtlar toplanma ve buluşma alanları kısaca mikro noktaları olmalıdır. Paris örneğinde bu mekânlar bu şekilde sınıflandırılmıştır. 


\begin{tabular}{|l|l|l|}
\hline Simgesel anıtlar & Akım oluşturan ya İkonik yapılar & Toplanma alanları \\
\hline$\bullet$ Eyfel Kulesı & $\bullet$ Eyfel Kulesı & $\bullet$ Konkorde Meydanı \\
$\bullet$ Georges Pompidou merkezi & $\bullet$ Georges Pompidou merkezi & $\bullet$ Şanzelize caddesi \\
$\bullet$ Louis vuitton foundation müzesi & $\bullet$ LouisVuitton foundation müzesi & \\
$\bullet$ Zafar Tağı & $\bullet$ LaVillette parkı & \\
& $\bullet$ Citroen Park & \\
\hline
\end{tabular}

$\mathrm{Bu}$ mekanların her hangisi bir kentin turistikin değerlerini yükseltebilir. Bu sebepten turisti artırmak için ikonik ve simgesel yapıların olduğu halde tanımlamamış ve tanıtılması yoksa tasarlanması gerekmektedir. Turistik kentlerin işlevel mekanların olması insanların cezb etmesinde önemli bir etkindir. İşlemvel binalar keyifli zaman geçirebilmek alanlardır, ayrıca yörenin kültürel geleneksel, veya sanatsal tanıtımını yapan diğer kültürlerden gelen insanlarla ortak paydaş bulma noktsı için çok önemlidir.Bu tip yapılar Paris örneğinde tarihi mekanlar, sergiler, kiliseler gibi mekanları içerir kentin kadım olması bu konuda çok önemlidir. Ancak yeni işlevsel mekanlarda bu konya destekçi olmuştur. Bu mekanlar sonuç olarak bu şekilde sınıflandırılabilir:

\begin{tabular}{|l|l|l|}
\hline Tarihi binalar & Dini binalar & Müze yapıları \\
\hline$\bullet$ Louvre müzesi & $\bullet$ Notre-Dame & $\bullet$ Orsay Müzesi \\
$\bullet$ Pantheon & $\bullet$ Sacré-Coeur Basilica & $\bullet$ Sacré-Coeur Basilica \\
$\bullet$ Orsay müzesi & $\bullet$ Pantheon & $\bullet$ Leorges Pompidou merkezi \\
$\bullet$ Sacré-Coeur Basilica & & $\bullet$ Versay müzesi \\
\hline Versay sarayı & & \\
\hline
\end{tabular}

Bu alanların çeşitliliği ve zengin olması turist sayısını artmasında en önemli faktörlerden biridir. Turistik amacı bir kentin planlamasını yaparken bu kültürel ve mekansal Zenginliğe yer verilmeli ve varsa bu konuda eksiklikler giderilmelidir. Diğer önemli ve dikkat edici husus kent ölçeğinde tanımlı olan alanlardır. Genelde bu anlanlar rekreasyonel ve yeşil alanlardır. Bu alanlar dolaşıma, toplanma, buluşma ve keyfli zaman geçirmek için gerekli alanlardır. Bu mekanlarda landmark (tanımlı leke) olması en önemli noktadır. Paris örneğinde Lavillette parkı, Citroen park, kent merkezindeki yeşil alan bu konuyun örneği olmuştur.

\begin{tabular}{|l|l|}
\hline Parklar ve Yeşil alanlar & Kent Meydanları \\
\hline$\bullet$ LaVillette parkı & $\bullet$ Konkorde meydanı \\
$\bullet$ Citroen park & $\bullet$ Şanzelize caddesi \\
$\bullet$ Versay bahçesi & \\
\hline
\end{tabular}

Son olarak Paris'i turistik kent yapmada bu üç faktörün çeşitli mekânlarda bir arada olmasıdır. Paris Örneğinden yola çıkarak elde edilen bulguları bu şekilde sınıflandırılmıştır:

- Zengin bir turistik kent faktörlerinden ikonik yapıların çeşitliliği ayrıca hem tarihi ve hem çağdaş şeklinde olmasıdır.

- Genelde bu mekânların tanımlı bölge olması ulaşım, dolaşım ve bulunması için gerekli konulardan biridir.

- Turistik mekânların dağılımı ve birbiriyle mesafeleri insanların olduğu kadar ile yürüme mesafeli veya ulaşım sistemine yakın olmasıdır.

- Kentlerin turistik planları hazırlanmalı ve bu üç faktörü içeren konular olduğu kadar ile aynı bölgede olmalıdır. Bu bölgelendirme Paris kentinde en iyi şekli ile yapılmış ve analizlerde gösterilmiştir.

- Her bölge için eşit dağlım yapılmalı ve yeni bina tasarımları bu konuya göre ayarlanmalıdır.

İkonik ve simgesel binalar kenti tanımlı kılması ve kimlik kazandırılmasında en önemli faktörlerden biridir. Mutlaka turistik kentin, bir veya birkaç marka binası olmalı, bu konuda eğer eski veya tanınmış kültürel anıtsal bina yoksa, yeni bir simgesel bina tasarlanmalıdır. 


\section{References}

Akyol, C.; Güner, S.; Oğan, Y.; Aydın, E.; Yüce, R. \& Uluyurt, T. (2014). "Kırsal Alanların Turizm Potansiyelinin Belirlenmesi - Artvin İli Arhavi İlçesi Örneği", Atatürk Üniversitesi Sosyal Bilimler Enstitüsü Dergisi, 18 (1), 249-271.

Boniface, P., (2013). Managing Quality Cultural Tourism (Heritage: Care-Preservation Management), Routledge Press.

Çelik Başok, G. (2017). Authentic Walling Technique of Traditional Houses in Akseki: Case Study on Ormana, ATA Planlama ve Tasarım Dergisi, 1 (1), 69-77.

Çelik Başok, G.; Er Akar, A.; Zamur Koçak, S. \& Örmecioğlu, H. T. (2021). " Ahşap Sütunlu Camilerin Taşıyıcı Sistem Performansı: Hanönü Yukarı Küreçayı Cami Örneği", Online Journal of Art and Design 9(3).

Doraj P. (2020). Geçmişten Günümüze Peyzaj Desen Dili Prensiplerinin Kentsel Yeşil Alanlara Yansima Analizleri, Phd thesis, University of Ataturk, Erzurum.

Dumont, E.; Ruelle, C. \& Teller, J. (2005). Pro- Active Management of the Impact of Cultural Tourism up on Urban Resources and Economies, European Commission.

Edwards, D.; Griffin, T. \& Hayllar, B. (2008). Urban Tourism Precincts: An Overview of Key Themes and Issues, Tourism Places: Urban Tourism Precincts, Elsevier, Oxford.

Estifanos, D. (2009). Cities and Culture City, Routledge press, London, United Kingdom.

Gemmiti, R. (2012). Urban Competiveness, Culture and Tourism. Critical Aspect in Rome Planning Experience, Universita degli Studi di Roma, Roma.

Habib, F., \& Huseininia, M. (2012). "An Analytical Approach to the Role of Urban Space in Attracting Cultural Tourist", American Journal of ientific Research, 71(15), 109-125.

Hossein Eskandani, O. (2020). Peyzaj Mimarlığı İle İlişkili Göstergelerin Doğu ve Batı Kültüründe Peyzaj Tasarımı Üzerine Etkisi, Phd thesis, University of Ataturk, Erzurum.

Hossein Eskandani, O. \& Doraj, P. (2021). "Redevelopment of Brownfields, an Approach toward Sustainable Local Development", Turkish Journal of Computer and Mathematics Education (TURCOMAT), Research Article, 12 (13), 4808-4815.

Jelincic, D. A. (2001). "Crotian Cultural Tourism Development Strategy. A Driving Force for Urban Tourism Application of Experiences to Countries in Transition", The1st International Seminar on Culture, May 18-19, pp. 1-6, Dubrovnik: Institute for International Relation.

Law, C. M. (1992). "Urban Torism and its Contribution to Economic Regeneration", Urban Studies, $29(3,4), 599-618$.

Lefebvere, H. (1990). The Production of Space, US New England states, Massachusetts.

Pearce, P. (1991) Analysing tourist attractions. Journal of Tourism Studies 2 (1), 46-55.

Plaza, B. (2000). "Evluting The Influence of a Large Cultural Artifact in The Attraction of Tourism (The Guggenheim Museum Bilbao Case)", Urban Affairs Review, 36(2), 17-41. 
Richards, G. \& Wilson, J. (2006). "Developing Creativity in Tourist Experiences: A Solution to the Serial Reproduction of Culture", Tourism management Journal, 27 (15), 1209-1223.

Schulz C.N. (1988). Architecture, Meaning and Place, Rizzoli International Publications, New York.

Schulz, C. N. (1980). Genius loci: towards a phenomenology of architecture. US Midwestrn states, Michigan

Soja, E. (1990). Postmodern Geographies. The Reassertion of Space in Critical Social Theory. London.

Strange, C. \& michael, K. (2002). "Shades of Dark Tourism Alcatraz and Robben Island. Annals of Tourism Research", 30 (2), 386-405.

Şahin. M. \& Akdoğdu, P. (2004). "Bilişim Teknolojilerindeki Gelişmelerin Turizm Sektörüne Etkisi ve Kullanım Alanları. п.", Ulusal Bilgi, Ekonomi ve Yönetim Kongresi. İzmit: Kocaeli Üniversitesi, 343-352. www.projepelit.com/proje3/kaynaklar/MAKALE\%205. doc (15.03.2021).

Tschurni, B. (1990). Questions of Space: Lectures on Architecture. The University of California.

Uriely, N. (2005). "The Tourist Experience Conseptual Development", Annals of Tourism Research, 32 (1), 199-216.

Yezdi, P.; Muhammadi, H. \& Segayi, M. (2007). Turistik kavramı, Tahran, Semt Press.

Yilmaz, S.; Doraj, P. \& Hossein Eskandani, O. (2020). "Concepts in Sustainable Architecture and Critical Approaches On The Ecological Effect", The Journal of International Social Research, Vol. 13, Issue 69, pp. 695-703. 